\title{
KUALITAS ILUSTRASI BUKU TEKS TEMATIK TERPADU TEMA “KELUARGAKU” JILID 1D TERBITAN ERLANGGA
}

\author{
Lusiatania Ayu, Noor Riyadhi \\ Program Studi Penerbitan, Jurusan Penerbitan \\ Politeknik Negeri Media Kreatif Jakarta
}

\begin{abstract}
This research aims to examine the quality of the illustration image in an integrated thematic textbooks for the theme of "Keluargaku" Vol 1D published by Erlangga. The researcher uses a qualitative descriptive method, with literary research, observation and interview. In the end, it can be concluded that there are errors of as much as 30\% illustration images and the use of the illustration is not fully in accordance with the concept of thematic for Curriculum 2013. First, the layout of illustrations in this book are already onsite according to the style that is applied by the publisher. Second, the depiction of the characters in this book not quite maximum. Third, representations of techniques in this book are computerized process thoroughly. Fourth, the quality of the illustrations in this book concerns three aspects, namely: mouth-watering readers, the quality of the message, as well as clarity and precision.
\end{abstract}

Keywords: illustration images, thematic textbooks, Curicullum 2013

\section{PENDAHULUAN}

Buku teks yang digunakan di dunia pendidikan di Indonesia harus memenuhi standar penilaian buku teks pelajaran, sebagaimana diatur dalam PP Nomor 19 Tahun 2005 "Kelayakan isi, bahasa, penyajian, dan kegrafikaan buku teks pelajaran dinilai oleh Badan Standar Nasional Pendidikan dan ditetapkan dengan Peraturan Menteri." Kelayakan kegrafikaan buku teks pelajaran dapat dinilai dari (1) tata letak unsur grafika estetis, dinamis, dan menarik serta menggunakan ilustrasi yang memperjelas pemahaman materi buku, (2) tipografi yang digunakan mempunyai tingkat keterbacaan yang tinggi, dan (3) ilustrasi dan tata letak mempermudah pemahaman materi.

Dalam penerbitan buku teks pelajaran, ilustrasi tentunya sangat penting untuk memperjelas naskah yang ada. Ilustrasi dapat menerangkan atau menghiasi suatu cerita, tulisan, puisi, atau informasi tertulis lainnya. Diharapkan dengan bantuan visual, tulisan tersebut lebih mudah dicerna. Pembuatan ilustrasi bisa dilakukan secara konvensional dan digital. Pembuatan ilustrasi secara konvensional melalui tahap, yaitu membuat sketsa, memberi warna, memindai gambar ke komputer (scanning) lalu menyempurakannya di layar 
komputer. Pembuatan ilustrasi secara digital berarti seluruh tahapan tersebut dilakukan dengan cara komputerisasi. Seiring dengan berkembangnya teknologi komputer, kini ilustrasi dapat dibuat dengan berbagai program, seperti Adobe Illustrator, Macromedia Freehand, CorelDraw, CorelPainter, Easy Paintool SAI, Adobe Photoshop, Paint dan Art Rage. Keberadaan program ini tentunya dapat mempermudah proses pengerjaannya, seperti membuat ilustrasi yang baru dan melakukan proses modifikasi.

Terkait dengan ilustrasi buku, penulis tertarik untuk mengkaji lebih dalam sebuah buku tematik Kurikulum 2013 terbitan penerbit Erlangga. Buku tersebut adalah Buku Teks Tematik Terpadu Tema Keluargaku Jilid 1D. Ada beberapa alasan mengapa penulis tertarik menggunakan buku tersebut sebagai objek kajian. Pertama, buku ini merupakan terbitan penerbit buku pelajaran terbesar di Indonesia dan menjadi buku yang sedang populer di antara buku teks pelajaran lainnya. Kedua, buku tematik merupakan program baru yang dicanangkan oleh pemerintah. Ketiga, kualitas ilustrasi buku ini pada dasarnya sudah baik, namun masih ada beberapa bagian yang sebaiknya diperbaiki pada edisi revisinya. Keempat, orang awam dapat menilai buku ini bagus karena banyak gambar dan banyak warna, namun bagi orang yang memiliki pengetahuan tentang kelayakan buku, buku ini memiliki beberapa kelemahan yang mencolok. Kelima, buku ini diselesaikan dalam waktu yang singkat sehingga secara simultan dikerjakan oleh beberapa ilustrator. Keenam, karena dikerjakan oleh beberapa ilustrator, dampaknya ada beberapa ketidakkonsistensian pengatakan ilustrasi dan penggambaran tokoh dalam buku tersebut. Ketujuh, untuk memenuhi banyaknya permintaan ilustrasi, para ilustrator memanfaatkan ilustrasi lain dengan cara memodifikasinya.

Penelitian ini penting untuk dilakukan dengan dua pertimbangan yang mendasar. Pertama, sebagai mahasiswa Program Studi Penerbitan, penulis ingin mengaplikasikan pengetahuan tentang buku pada umumnya dan pengetahuan tentang ilustrasi pada khususnya sehingga penulis dapat menjelaskan apakah ilustrasi yang digunakan dalam buku ini sudah memenuhi standar kualitas untuk buku tematik. Kedua, simpulan dari penelitian ini dapat menjadi sumbangsih penulis untuk penerbit Erlangga. Jika ada kelebihan ataupun kelemahan terhadap kualitas ilustrasi mereka, maka hasil Tugas Akhir ini dapat dijadikan sebagai salah satu sumber perbaikan/pengembangan untuk edisi revisi buku tersebut. Berdasarkan latar belakang tersebut maka penelitian ini bertujuan untuk mendeskripsikan pengilustrasian Buku Teks Tematik Terpadu Tema Keluargaku Jilid $1 D$ dalam hal pengatakan ilustrasi, penggambaran tokoh, dan kualitas ilustrasi. 
Dalam Kamus Besar Bahasa Indonesia (2008:58) kata "kajian" memiliki makna: (1) penyelidikan terhadap suatu peristiwa (karangan, perbuatan, dsb) untuk mengetahui keadaan yang sebenarnya (sebabmusabab, duduk perkara, dsb); (2) Man penguraian suatu pokok atas berbagai bagiannya dan penelaahan bagian itu sendiri serta hubungan antarbagian untuk memperoleh pengertian yang tepat dan pemahaman arti keseluruhan; (3) Kim penyelidikan kimia dengan menguraikan sesuatu untuk mengetahui zat bagiannya dsb; (4) penjabaran sesudah dikaji sebaikbaiknya; dan (5) pemecahan persoalan yang dimulai dengan dugaan akan kebenarannya. Dalam hal ini, yang dimaksud dengan analisis adalah penyelidikan terhadap ilustrasi dalam buku pelajaran sekolah dasar untuk mengetahui keadaan yang sebenarnya.

Selanjutnya, dalam buku Taktis Menyunting Buku (2009:51) dijelaskan bahwa penerbit ada yang disebut penerbit umum dan ada juga penerbit khusus. Penerbit umum artinya penerbit yang menerbitkan buku populer ataupun ilmiah secara umum. Sedangkan penerbit khusus atau spesialis adalah penerbit yang mengkhususkan jenis terbitannya, misalnya penerbit buku pelajaran, buku perguruan tinggi, penerbit buku rohani, penerbit buku anak dan remaja dan lainnya. Jenis penerbit yang paling banyak di Indonesia adalah penerbit buku teks atau buku pelajaran. Hal itu terlihat dari banyaknya jumlah lowongan kerja di penerbit buku teks di media massa. Jenis kedua yang termasuk paling banyak adalah buku rohani yang mengalami perkembangan sejak awal tahun 1980-an.

Kegiatan penerbitan secara eksternal merupakan pusat dari seluruh komponen rekan kerja penerbitan. Dalam industri buku mereka menjadi kelompok yang menggerakkan kegiatan industri buku. Sedangkan secara internal penerbit, terdiri dari bagian utama seperti: editing, produksi, pemasaran dan distribusi, bagian administrasi keuangan serta bagian kepegawaian (HRD/Human Resource Development).

Dalam buku Pengetahuan Penerbitan (2007:31) dikatakan bahwa seluruh komponen penerbit pada dasarnya bertugas melakukan perencanaan penerbitan dan editorial, memperoleh naskah, menentukan diterima atau tidaknya sebuah naskah, memberi petunjuk kepada pengarang sewaktu menulis, menggarap naskah dan memandu produksi, dan memasarkan.

Kurikulum 2013 pada jenjang SD menggunakan tematik terpadu. Hal itu dikarenakan sesuai dengan tingkatan usia, serta jenjang pendidikan, siswa SD secara psikologis belum membutuhkan pengetahuan yang spesifik, melainkan butuh pengetahuan yang lebih umum tapi komprehensif menurut buku Kurikulum 2013 Tanya Jawab. Sehingga untuk memudahkan memahami pelajaran dan mengetahui apa yang ada di sekitar mereka dibutuhkan pendekatan berbasis tematik yang 
terpadu, yang erat kaitannya dengan kehidupan di sekeliling mereka.

Kurikulum 2013 memiliki tiga ciri. Pertama, jika pada Kurikulum Tingkat Satuan Pendidikan (KTSP) 2006, mata pelajaran ditentukan dahulu di dalam menetapkan standar kompetensi lulusan, maka pada Kurikulum 2013 pola pikir tersebut dibalik. Kompetensinya ditetapkan terlebih dahulu berdasarkan kebutuhan, baru kemudian mata pelajarannya. Kedua, Kurikulum 2013 memiliki pendekatan lebih utuh, berbasis pada kreativitas siswa. Kurikulum 2013 disusun terapadu antara mata pelajaran satu dengan lainnya, sehingga tiga komponen utama pendidikan, yaitu; sikap, keterampilan, dan pengetahuan dijadikan penguatan pada pembentukan karakter siswa. Ketiga, Kurikulum 2013 kompetensi pada tiap jenjang SD, SMP, SMA didesain secara berkesinambungan dan utuh.

Buku Teks Tematik Terpadu Tema Keluargaku Jilid $1 D$ berbasis Kurikulum 2013. Dalam buku Kurikulum 2013 Tanya Jawab dijelaskan Kurikulum 2013 adalah kurikulum berbasis kompetensi yang dirancang untuk mengantisipasi kebutuhan kompetensi abad 21. Kompetensi ini dirancang untuk dicapai melalui proses pembelajaran berbasis penemuan (discovery learning) melalui kegiatan-kegiatan berbentuk tugas (project based learning) yang mencakup prosesproses mengamati, menanya, mencoba, menalar, dan mengkomunikasikan.
Buku Teks Tematik Terpadu Tema Keluargaku ID merupakan bagian dari Kurikulum 2013 yang diterbitkan oleh Penerbit Erlangga. Buku Teks Tematik Terpadu ini menyajikan kompetensi inti dan kompetensi dasar dengan berbagai pendekatan bidang studi melalui tema. Dalam buku ini ada lima mata pelajaran yang disajikan secara tematik terpadu yaitu PPKn (Pendidikan Pancasila dan Kewarganegaraan), Bahasa Indonesia, Matematika, SBP (Seni Budaya dan Prakarya), dan Penjasorkes (Pendidikan Jasmani Olahraga dan Kesehatan).

Buku ini menyajikan ilustrasi gambar yang cukup banyak karena ditujukan untuk kelas 1 SD. Ada ilustrasi yang berwarna dan ada juga yang hitam putih. Tokoh utama dalam buku ini adalah Nina. Hal itu dikarenakan dalam satu buku hanya menggunakan satu tokoh utama.

Program tematik terpadu tersebut diimplementasikan dalam buku Teks Tematik Terpadu Tema Keluargaku Jilid $1 d$ terbitan penerbit Erlangga. Penerapan aturan tematik tersebut memang tidak baku, tetapi memang ada aturan yang paling mendasar untuk buku kelas $1 \mathrm{SD}$, yaitu:
a. Memiliki satu tokoh sentral untuk tiap buku
b. Menggunakan font yang tidak berkait
c. Besar huruf $\pm 16 \mathrm{pt}$
d. Ukuran buku \pm A4 (21 x 29,7 $\mathrm{cm}$ )
e. Jumlah halaman $>100$ halaman 
Menurut Roger Seguin dalam buku The Elaboration Of School Textbooks Methodological Guide di Division of Educational Sciences, Contents and Methods of Education Unesco telah ditentukan beberapa karakteristik dan kualitas ilustrasi yang baik meliputi:

a. Menggugah Selera Pembaca ( How Evocative is it)

Penggabungan elemen-elemen afektif dan estetika ke dalam suatu ilustrasi. Realisme warna ilustrasi akan merangsang minat murid untuk membaca. Sudut pandang ilustrasi dapat lebih efektif daripada gambar (pemandangan, potret, adegan dari kehidupan sehari-hari di daerah lain). Selain itu, anakanak lebih mengutamakan membaca gambar daripada teks karena kekuatan mereka tergugah untuk melihat contoh yang ada.

b. Kualitas Pesan yang Ditransmisikan (The Quality of the Message Transmitted) Suatu ilustrasi dalam buku anak pasti memiliki pesan yang ingin disampaikan. Hal ini sering digambarkan secara rinci untuk menjadi lebih baik menekankan objek atau pengalaman yang akan disorot. "Membaca" sebuah gambar membuat murid lebih banyak menangkap informasi yang akurat daripada foto yang tidak membawa cukup detail yang signifikan.

c. Kejelasan dan Ketepatan (Clarity dan Accuracy)
Ilustrasi harus menggambarkan dan menjelaskan apa yang dijelaskan dalam teks tertulis. Ilustrasi harus jelas dan akurat agar tidak menimbulkan ambiguitas. Dari sudut pandang ini, ilustrasi lebih efektif daripada foto. Ilustrator akan bekerja sesuai dengan brief dari editor untuk menggambar karakter, benda, dan elemen yang berbeda. Ilustrasi dekoratif dibenarkan untuk merangsang dan mengembangkan kepekaan artistik murid. Buku-buku sekolah harus menarik, gambar dekoratif untuk estetika seharusnya tidak digunakan. Namun, berfungsi untuk menyembunyikan kelemahan dari tujuan dan konten teks. Setiap aspek artistik yang dimasukkan ke dalam teks harus memiliki fungsi pedagogis.

\section{METODE PENELITIAN}

Objek kajian yang penulis gunakan adalah Buku Teks Tematik Terpadu Tema Keluargaku ID terbitan Erlangga. Buku ini disusun oleh Dra. Dwi Tyas Utami, M.Pd dan Irene Maria Julia Astuti, M.Pd dan diterbitkan oleh penerbit Erlangga pada tahun 2013. Buku ini diedit oleh Dian Anggraeni, S.Si, Riski Candra, S.Si, Ch. Eny Wijayanti, M.Pd, dan Bambang Sutrisno, M.Pd. Buku teks ini dicetak di PT Gelora Aksara Pratama.

Dalam buku Qualitative Research for Education An Introduction to Theory and Methods, 
Bogdan dan Biklen merangkum adanya lima ciri yang merupakan karakteristik penelitian kualititif pada umumnya, yaitu (1) natural setting, sebagai sumber data langsung dan peneliti sebagai instrumen kunci, (2) bersifat deskriptif, mengutamakan proses daripada hasil, (4) analisis data secara induktif, dan (5) makna/meaning merupakan perhatian utamanya. (1982, 27-30). Penulis menggunakan metode kualitatif deskriptif. Fokusnya adalah penggambaran ilustrasi Buku Teks Tematik Terpadu Tema Keluargaku $1 D$ terkait Tata letak ilustrasi, penggambaran tokoh, teknik penggambaran, dan kualitas ilustrasi. Penggambaran tersebut berdasarkan pengetahuan dan kemampuan penulis sebagai subjek atau orang yang meneliti.

Untuk pengumpulan data, penulis menggunakan 3 (tiga) teknik, yaitu studi pustaka, observasi, dan wawancara. Pertama, studi pustaka dilakukan dengan mencari data-data referensi dalam buku Penulisan Buku Teks Pelajaran, Desain Komunikasi Visual Teori dan Aplikasi, Integrating Language Arts Through Literature and Thematic Units, The Elaboration Of School Textbooks Methodological Guide, Kurikulum 2013 Tanya Jawab dan Opini. Kedua, obervasi dilakukan dengan mengamati kegiatan-kegiatan di penerbit Erlangga sewaktu penulis melaksanakan kegiatan Praktek Industri yang terkait pada pembuatan ilustrasi dari brief hingga menjadi ilustrasi yang utuh dalam penulisan
Tugas Akhir ini. Terakhir, wawancara dilakukan dengan cara mencari data-data akurat dari narasumber di penerbit Erlangga pada bulan Maret 2014, yaitu Bapak Bambang Sutrisno, M.Pd sebagai Direktur Pjs Produksi, dan Bapak Raga sebagai Editor Multimedia. Penulis juga melakukan wawancara dengan Ibu Christine Tulalessy, M.Pd sebagai Editor di Pusat Kurikulum dan Perbukuan dan Bapak Gunawan sebagai Ilustrator kurikulum 2013 pada bulan April 2013.

\section{Tata Letak Ilustrasi Buku Teks Tematik Terpadu Tema Keluargaku Jilid 1D}

Segi Fisik Buku, Berdasarkan Buku Pintar Penyuntingan Naskah Edisi Revisi (2012:144) segi fisik suatu buku yang dijadikan penilaian dasar terdiri dari beberapa bagian. Beberapa diantaranya yaitu jenis kertas, ukuran buku, jumlah halaman, penggunaan warna, ilustrasi dan kualitas cetak.

Jenis kertas, Pada Buku Teks Tematik Terpadu Tema Keluargaku Jilid $1 D$ ini, jenis kertas yang digunakan pada cover adalah Art Carton 230 gram. Sedangkan untuk halaman isi menggunakan kertas HVS 70 gram.

Jumlah halaman, Jumlah halaman Buku Teks Tematik Terpadu Tema Keluargaku Jilid ID adalah 112 halaman sehingga menggunakan kateren kelipatan 8 sehingga satu buku memiliki 14 kateren. 


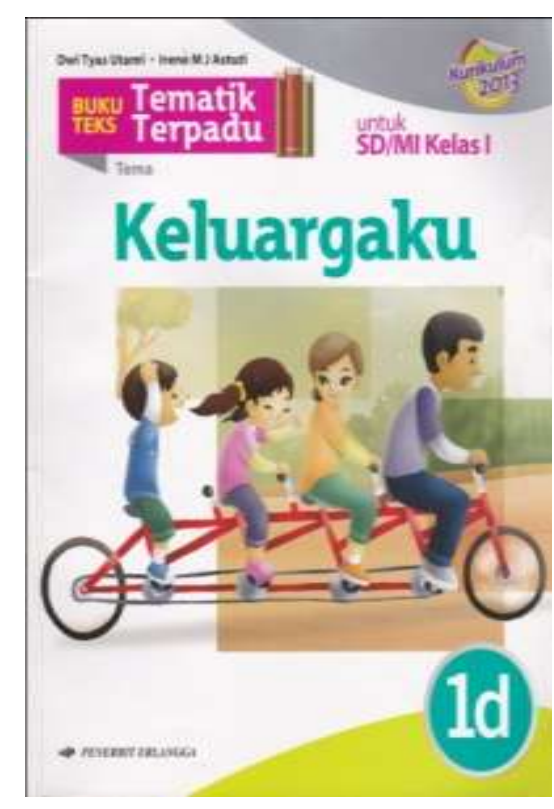

Gambar 3.1 Buku Teks Tematik Terpadu Tema Keluargaku Jilid $1 D$

Ukuran buku, Pada Buku Teks Tematik Terpadu Tema Keluargaku Jilid $1 D$ ini, ukuran bukunya adalah $21 \times 26 \mathrm{~cm}$ dengan berat 276 gram. Ukuran buku ini juga digunakan pada buku pendamping tematik terpadu mata pelajaran.

Penggunaan warna, Buku Teks Tematik Terpadu Tema Keluargaku Jilid $1 D$ untuk bagian cover dan bagian isi menggunakan fullcolour.

Ilustrasi, Buku Teks Tematik Terpadu Tema Keluargaku Jilid 1Dterdiri dari 363 gambar. Gambar ilustrasi terdiri dari 360 buah dan 3 foto.

Font, Buku Teks Tematik Terpadu Tema Keluargaku Jilid $1 D$ menggunakan font yang tidak berkait. Untuk buku terbitan Erlangga, font yang digunakan adalah Huruf Denmas dengan ukuran 16 pt. Font ini merupakan font yang dibuat oleh penerbit Erlangga.

Tata Letak Ilustrasi, Grid berfungsi sebagai alat bantu dalam mengatur tata letak elemen-elemen di dalam naskah. Pada Buku Teks Tematik Terpadu Tema Keluargaku Jilid $1 D$ ini, grid digunakan untuk mengatur elemen-elemen visual yaitu teks dan ilustrasi. Tujuan menggunakan grid agar tata letak ilustrasi dapat sejajar dan terlihat teratur antara ilustrasi yang satu dengan yang lain.

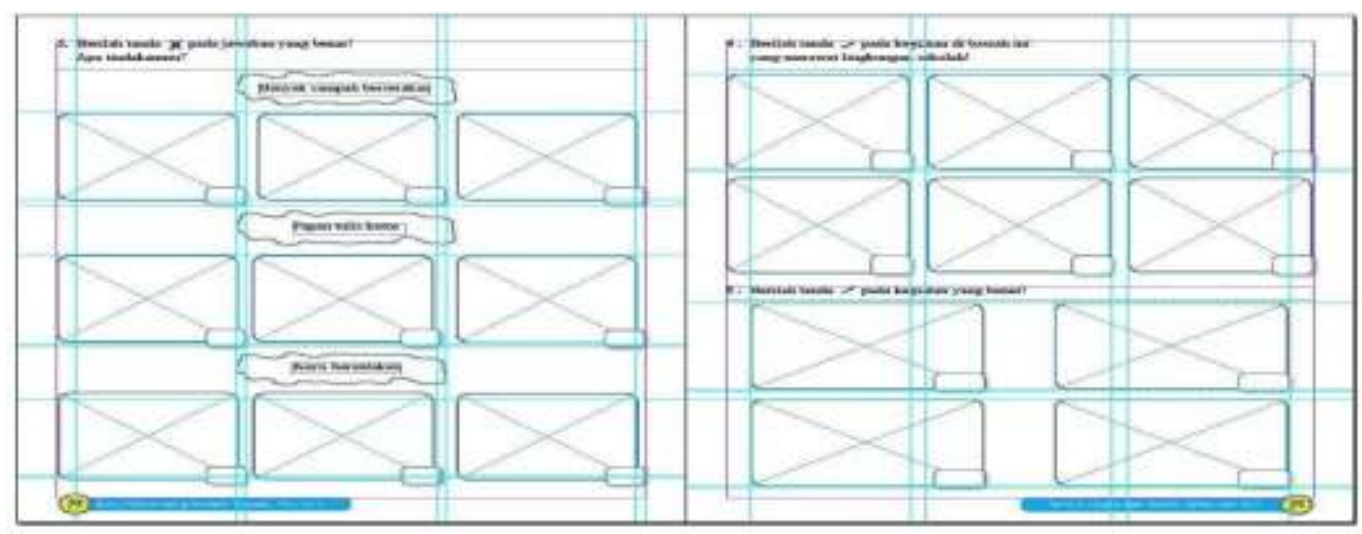

Gambar 3.3. Contoh grid dalam buku 


\section{b. Penggambaran Tokoh di Buku} Teks Tematik Terpadu

Dalam buku tematik khususnya untuk kelas 1 SD hanya memiliki satu tokoh sentral. Menurut Ibu Christine sebagai Editor di Pusat Kurikulum dan Perbukuan hal itu

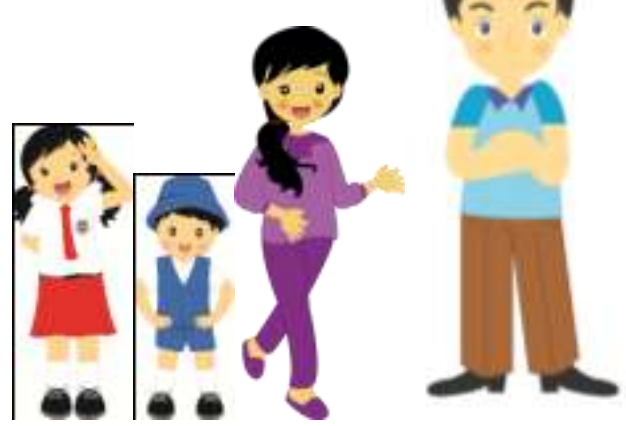

Gambar 3.4.Nina, Adi, Ibu dan Ayah

Ilustrasi di penerbit Erlangga mempunyai standar ilustrasi yang harus diperhatikan. Hal ini berguna untuk membedakan setiap karakter tokoh yang digambar. Menurut Bapak Raga sebagai Editor Multimedia di penerbit Erlangga standar ilustrasi itu meliputi: standar ilustrasi tokoh anak, standar perbandingan tinggi tokoh, standar baju seragam.

\section{c. Karakter dalam Buku Teks Tematik Terpadu}

Suatu buku pasti memilki karakter tokoh untuk membangun cerita yang ingin disampaikan.

"Characters are who the story is about, and the action revolves around them. Authors develop characters primarily from three sources: (1) from the narrator's description of physical appearance and personality; (2) from other characters-what others think of characters and what others' actions dikarenakan karena kondisi psikologi anak-anak yang berpusat hanya pada satu orang saja. Contohnya dalam BukuTeks Tematik Tema Keluargaku Jilid $1 D$ ini ilustrasinya hanya menggambarkan Nina dan keluarga intinya saja.

are toward them; and (3) from the characters themselves-what they think, what they say, and what they do. Expect the latter to be the most revealing. Through actions, the most convincing evidence about character is revealed". Disarikan dari laman www.pearsonhighered.com/assets/hi p/us/hip_us_pearsonhighered/sample chapter/0132685833.pdf (diakses 23 Mei 2014 pukul 21.00).

Paragraf di atas menjelaskan penggambaran karakter adalah kunci utama sebuah buku. Karakter yang diciptakan sesuai dengan naskah yang sudah ada. Karakter dikembangkan dari tiga sumber yaitu:

a. Penciptaan karakter bisa menampilkan kepribadian dan fisik tokoh dalam buku ini adalah Nina, Adi, Ayah dan Ibu. Mereka digambarkan berbeda satu sama lain agar 
pembaca

dapat

membedakannya.

Tabel. 3.1 Penggambaran Karakter

\begin{tabular}{l} 
Nina digambarkan sebagai sosok yang periang. \\
Nina adalah siswi sekolah dasar. \\
$\begin{array}{l}\text { Adi merupakan adik Nina. Adi digambarkan } \\
\text { lebih kecil dari kakaknya. Adi adalah siswa } \\
\text { taman kanak-kanak. }\end{array}$ \\
$\begin{array}{l}\text { Ibu digambarkan sebagai sosok yang } \\
\text { penyayang. Pekerjaan Ibu adalah seorang guru. }\end{array}$ \\
\hline $\begin{array}{l}\text { Ayah digambarkan sebagai sosok yang dewasa. } \\
\text { Pekerjaan Ayah adalah seorang arsitek. }\end{array}$
\end{tabular}

b. Karakter lain yang mendukung dan kegiatan yang dilakukan bersama. Tokoh utama dalam buku Teks Tematik Terpadu Tema Keluargaku Jilid 1Dadalah Nina. Karakter lain yang mendukung tokoh Nina yaitu Lani, Deli, Joni, Siti, Toni, Made. Gambar di bawah ini menggambarkan Nina sedang bermain bersama teman-temannya.

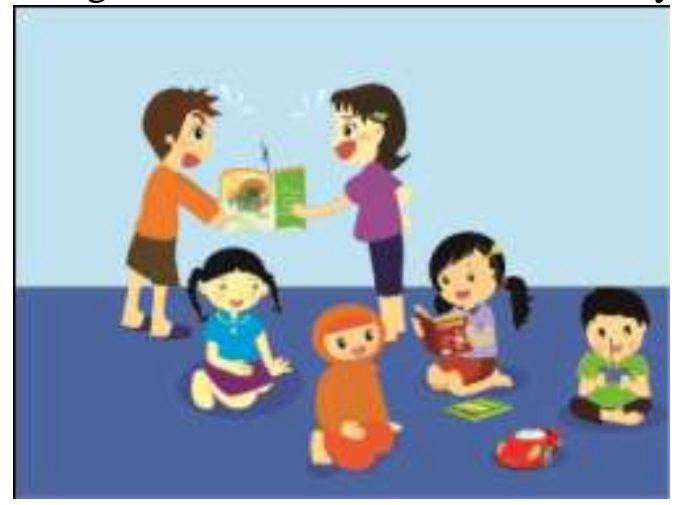

Gambar 3.9.

Nina bermain dengan teman-temannya 
c. Karakter pribadi yang mendukung kegiatan, apa yang dipikirkan dan dikatakan. Contohnya karakter Nina digambarkan di bawah ini.

\begin{tabular}{|c|c|}
\hline \multicolumn{2}{|c|}{ Tabel. 3.2 Karakter Nina } \\
\hline Ekspresi marah \\
Nina sedang
\end{tabular}

Program tematik terpadu tersebut diimplementasikan dalam buku Teks Tematik Terpadu Tema Keluargaku Jilid $1 D$ terbitan

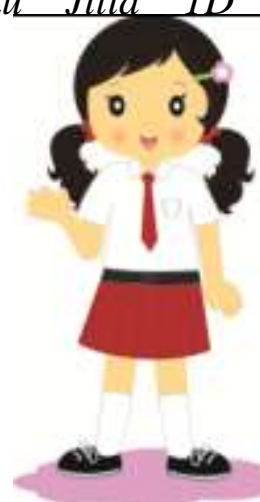

Gambar 3.10. Nina

Penggambaran karakter berkaitan dengan keindahan isi buku. Dalam buku ini ditemukan beberapa yang keliru sehingga menimbulkan kesan yang tidak enak dilihat. Beberapa contoh yang penulis temukan antara lain:

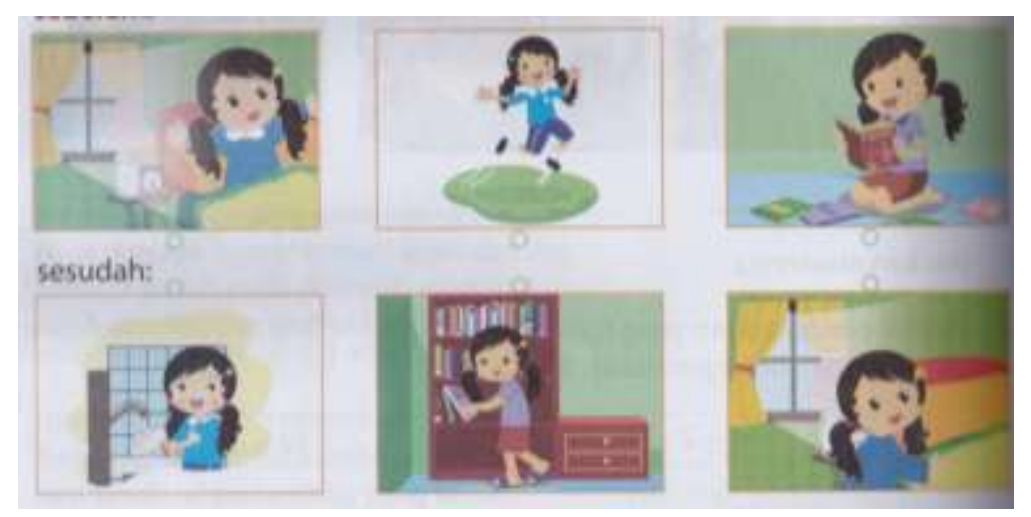

penerbit Erlangga. Penerapan aturan tematik tersebut dalam buku ini yaitu memiliki satu tokoh sentral yaitu Nina.
Gambar 3.11.

Ekspresi wajah Nina 
2. Posisi wajah yang hampir digambarkan menghadap ke depan ketika badan sedang menyamping. Posisi seperti ini banyak ditemukan dalam buku ini. Contohnya pada halaman 10 dan 16.

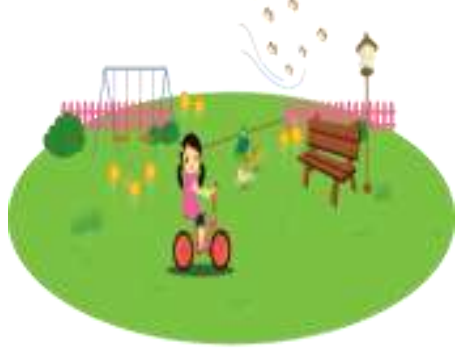

Gambar 3.12. Nina sedang naik sepeda

3. Posisi anggota tubuh yang tidak sesuai. Pada halaman 75 diilustrasikan keluarga Nina sedang bermain alat musik. Perhatikan posisi tangan Nina sebelah kanan, posisi tangan tersebut menunjukkan siku tangan

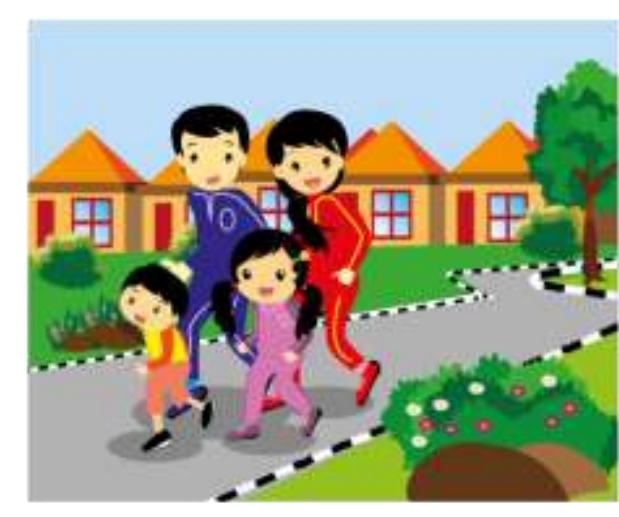

Gambar 3.13. Keluarga Nina lari pagi Nina berputar $360^{\circ}$. Perhatikan pula kondisi mulut ibu digambarkan sangat tidak proporsional dan posisi kaki ibu seharusnya menginjak bagian pedal saat bermain piano.

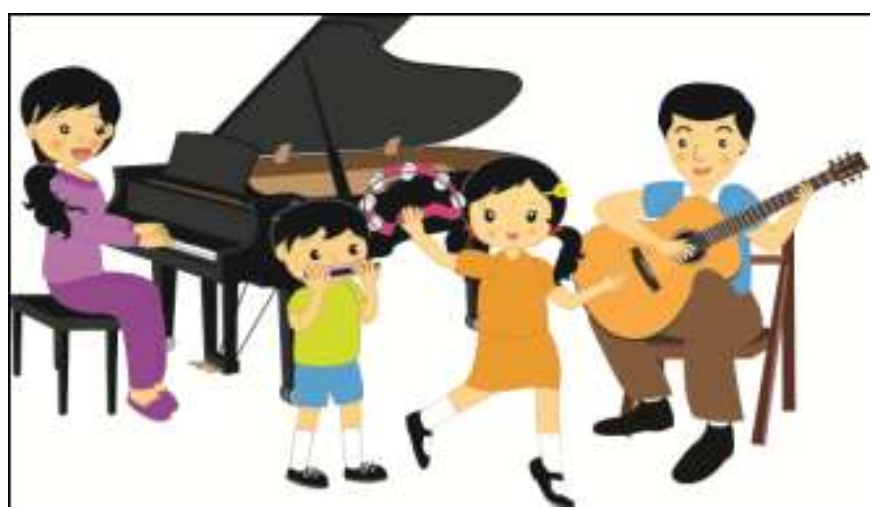

Gambar 3.14.

Nina dan keluarga sedang bermain musik

\section{d. Multikulturalisme dalam Buku}

Indonesia adalah negara yang indah. Setiap daerah di Indonesia memilki kebudayaannya sendiri. Keanekaragaman tersebut mempengaruhi penggambaran tokoh dalam buku pelajaran. Menurut B.D. Roe dan E.P. Ross dalam buku Integrating Language Arts Through Literature and Thematic Units dijelaskan bahwa
"Multicultural literature helps readers value people from different races, ethnic groups, and cultures. Excellent, well-illustrated books are available for many cultural groups. Children from such populations gain self-esteem by seeing themselves represented in books, and mainstream children begin to appreciate others from culturally diverse backgrounds. 
Indonesia memiliki 34 provinsi yang terdiri atas beragam suku bangsa dan budaya. Buku tematik seharusnya menggambarkan tokoh yang multikultural. Hal itu dilakukan agar anak-anak dari populasi tersebut mendapatkan kebanggaan melihat dirinya diwakili dalam buku dan diharapkan dengan hal ini anak-anak yang sering digambarkan

Tabel. 3.3 Penggambaran Karakter Multikultur

\begin{tabular}{|l|l|}
\hline & $\begin{array}{l}\text { yang digambarkan dengan mata } \\
\text { sipit. Dia merupakan keturunan } \\
\text { etnis Cina. }\end{array}$ \\
\hline
\end{tabular}

Tidak hanya penggambaran tokoh saja yang seharusnya beragam, penggambaran kondisi lingkungan sesuai kehidupan sehari-hari masyarakat Indonesia juga perlu digambarkan dalam buku tematik. Misalnya kondisi rumah, tanaman, hewan, halaman rumah, kondisi sekolah, kebiasaan masyarakat dan lainnya.

Penggambaran ilustrasi dalam buku tematik ini ada beberapa yang tidak sesuai dengan kehidupan sehari-hari masyarakat Indonesia. Hal tersebut tentunya akan memberikan penalaran yang berbeda terhadap perserta didik. Itu terlihat

Gambar 3.18.

Keluarga Nina menghargai orang lain dari latar belakang budaya yang berbeda. Multikulturalisme juga bisa digambarkan lewat warna. Misalnya warna merah untuk etnis Cina, warna biru untuk Eropa dan lainnya. Dalam buku ini hanya digambarkan sedikit suku, contohnya:

dari beberapa contoh yang penulis dapat dari buku tematik ini, antara lain:

1. Bangunan rumah di Indonesia seharusnya tidak menggunakan cerobong asap. Hal itu dikarenakan iklim Indonesia yang tropis sehingga tidak perlu adanya cerobong asap. Rumahrumah di negara dengan empat iklim yang menggunakan cerobong asap, misalnya Amerika, Italia, Inggris dan Belanda.

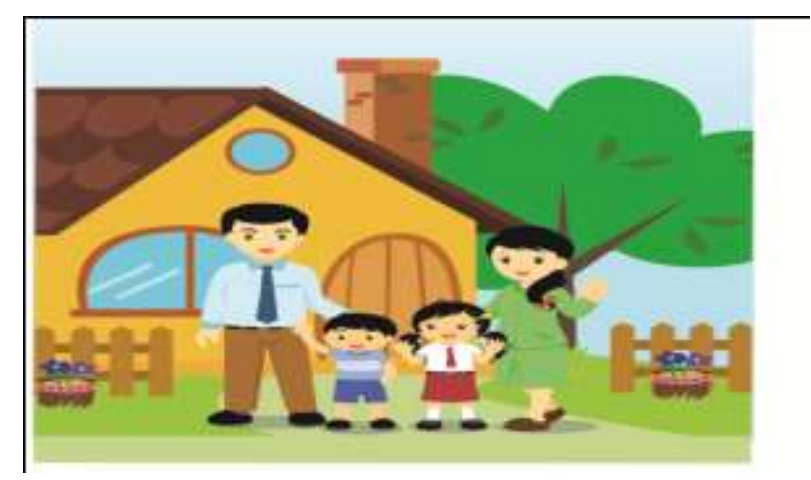


2. Suasana dalam rumah yang digambarkan terlalu kaku, tidak digambarkan kondisi rumah yang sesungguhnya. Pada halaman 27 diilustrasikan Nina dan keluarga sedang makan malam di rumah, di gambar itu terlihat Nina dan Adi menggunakan sepatu komplit dengan kaos kakinya. Padahal, mereka dalam suasana makan malam. Dalam kehidupan nyata masyarakat Indonesia tidak mungkin seperti itu.

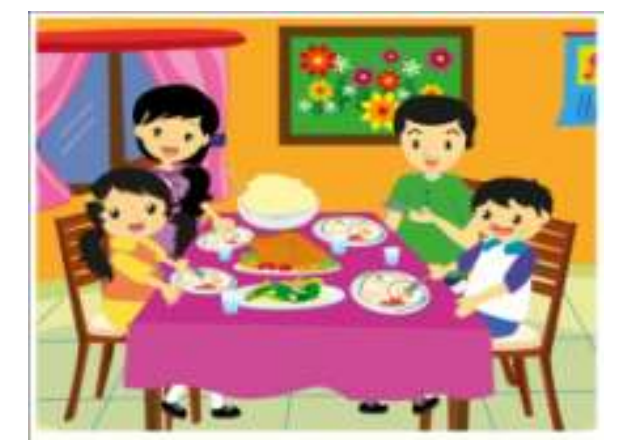

Gambar 3.19. Nina sedang makan malam bersama keluarga

3. Penggambaran ilustrasi pohon di buku ini tidak sesuai dengan kondisi nyata di lingkungan Indonesia, pada halaman 32 dan 44 pohon-pohon itu digambarkan hanya seperti pohon atau ada yang berbentuk lonjong.

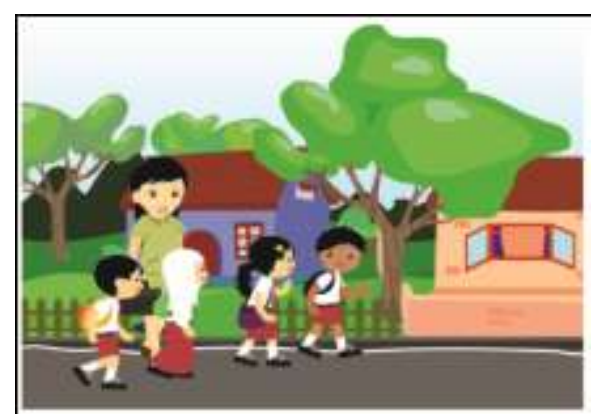

Gambar 3.20. Nina pulang sekolah bersama temannya

4. Penggambaran hewan di buku ini juga jauh dari kondisi nyata. Dalam ilustrasi rekreasi pada halaman 27 digambarkan Nina dan keluarga berkunjung ke kebun binatang. Disana terlihat panda dan domba yang bermain bersama. Kenyataannya di kebun binatang Indonesia sulit sekali ditemukan panda dan keberadaan domba seharusnya tidak digabungkan dengan panda.

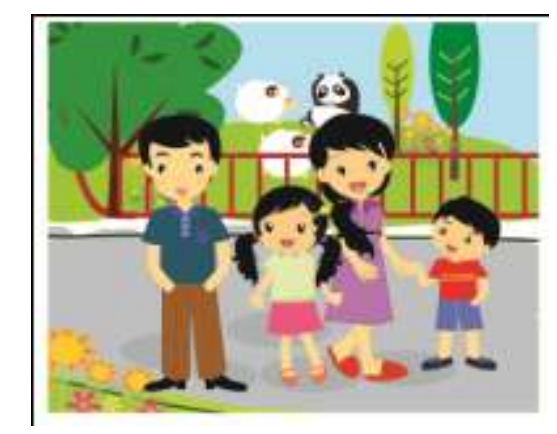

Gambar 3.21. Nina rekreasi bersama keluarga

\section{e. Kualitas Ilustrasi Buku Teks Tematik Terpadu Tema Keluargaku Jilid 1D}

Buku Teks Tematik Terpadu Tema Keluargaku Jilid $1 D$ terdiri dari empat Subtema, masing-masing Subtema terdiri dari enam Pembelajaran. Setiap pembelajaran memiliki jumlah ilustrasi yang berbeda-beda. 
Jumlah ilustrasi masing-masing adalah sebagai berikut:

Tabel. 3.4 Penghitungan Ilustrasi

\begin{tabular}{l|c|c|c}
\hline \multicolumn{1}{c|}{ Subtema } & $\begin{array}{c}\text { Gambar } \\
\text { fullcolor }\end{array}$ & Gambar BW & Foto \\
\hline Anggota Keluarga & 98 & 4 & - \\
Kegiatan Keluargaku & 74 & 4 & 3 \\
Aku \& Keluarga Besarku & 72 & - & - \\
Kebersamaan dalam Keluarga & 107 & 1 & - \\
Jumlah & 351 & 9 & 3 \\
TOTAL & \multicolumn{2}{|c}{$\mathbf{3 6 3}$} \\
\hline
\end{tabular}

Jumlah seluruh gambar : 363 gambar

Foto : 3 gambar

Ilustrasi : 360 gambar

- Ilustrasifullcolor : 351 gambar

- Ilustrasi black \& white: 9 gambar

Tabel. 3.5 Penghitungan ilustrasi yang keliru

\begin{tabular}{lc}
\hline \multicolumn{1}{c}{ Objek Penelitian } & $\begin{array}{c}\text { Jumlah } \\
\text { Gambar }\end{array}$ \\
\hline Penggambaran wajah yang terlihat patah dengan posisi badan & 59 \\
Ilustrasi yang tidak sesuai dengan konsep tematik lingkungan & 12 \\
Indonesia & 1 \\
Pewarnaan yang salah & 7 \\
Posisi tubuh yang salah & 4 \\
Perspektif gambar yang tidak sesuai & 3 \\
Ilustrasi yang tidak sesuai teks & 3 \\
Ilustrasi yang salah ekspresi wajahnya & 19 \\
Gambar yang diulang &
\end{tabular}

Jumlah ilustrasi

Ilustrasi yang keliru

Jadi, persentase ilustrasi yang keliru

Persentase ilustrasi yang benar

\section{PENUTUP}

Berdasarkan pembahasan pada bab sebelumnya, penulis menyimpulkan bahwa penggunaan ilustrasi pada Buku Teks Tematik
: 360 gambar

: 108 gambar

$: \frac{108}{360} \times 100 \%=30 \%$

$: \frac{252}{360} \times 100 \%=70 \%$

Terpadu Tema Keluargaku Jilid 1D terbitan Erlangga belum sepenuhnya sesuai dengan konsep tematik untuk Kurikulum 2013. Adapun kajian mendalam mengenai ilustrasi 
tersebut, penulis simpulkan sebagai berikut.

Pertama, tata letak ilustrasi dalam buku ini sudah sesuai dengan gaya selingkung yang diterapkan oleh penerbit. Penerbit juga telah menggunakan grid untuk membantu mempermudah tata letak. Kedua, penggambaran karakter dalam buku ini belum cukup maksimal, masih ditemukan beberapa ekspresi gambar yang sama dengan aktivitas berbeda.

Ketiga, kualitas ilustrasi dalam buku ini menyangkut tiga aspek, yaitu: menggugah selera pembaca, kualitas pesan yang disampaikan, serta kejelasan dan ketepatan. Ilustrasi dalam buku ini sudah menggugah selera pembaca dengan penggunaan warna-warna yang beragaman.

\section{DAFTAR RUJUKAN}

Erneste, Pamusuk. 2012. Buku Pintar Penyuntingan Naskah Edisi Kedua (Revisi). Jakarta: Gramedia Pustaka Utama.

Kusrianto, Adi. 2009. Pengantar Desain Komunikasi Visual. Yogyakarta: Penerbit Andi.

Owen, Peter. Editor. 1996. Publishing Now. London: Great Britain.

Perkins, Russell A. 2000. Directory Publishing: A Practical Guide. London: Havestraw Publishers.

Pusat Informasi dan Hubungan Masyarakat Kementerian Pendidikan dan Kebudayaan. 2013. Kurikulum 2013 Tanya
Jawab dan Opini. Jakarta:

Pusat Informasi dan Hubungan Masyarakat Kementerian Pendidikan dan Kebudayaan.

Pusat Pembinaan dan Pengembangan Bahasa. 2008. Kamus Besar Bahasa Indonesia. Cetakan ke-4. Jakarta: PT Gramedia Pustaka Utama.

Riyadhi, Noor dan Tri Marganingsih. 2006. Profesi di Penerbitan. Jakarta: Pusat Grafika Indonesia Departemen Pendidikan Nasional.

Ross, E.P. dan B.D. Roe. 2006. Integrating Language Arts Through Literature and Thematic Units. Pearson Education Inc. Tanpa Kota.

Sitepu. 2012. Penulisan Buku Teks Pelajaran. Bandung: PT Remaja Rosdakarya.

Smith, Datus C. 1992. Penuntun Penerbitan Buku. Jakarta: Pusat Grafika Indonesia.

Supriyono, Rakhmat. 2010. Desain Komunikasi Visual Teori dan Aplikasi. Yogyakarta: Penerbit Andi.

Trim, Bambang. 2009. Taktis Menyunting Buku. Jakarta: Salamadani.

Waloeya, Yohan Jati. 2010. Seri Belajar Kilat Adobe Illustrator CS5. Yogyakarta: Penerbit Andi.

Wibowo, Ibnu Teguh. 2013. Belajar Desain Grafis. Yogyakarta: Yayasan Buku Pintar. 